\title{
MORFOLOGI Sargassum sp DI KEPULAUAN RAJA AMPAT, PAPUA BARAT
}

\author{
(Morphology of Sargassum sp on Raja Ampat Archipelago, West Papua)
}

\author{
Jenita Pansing ${ }^{1 *}$, Grevo S, Gerung ${ }^{1}$, Calvyn F.A. Sondak ${ }^{1}$, Billy Th Wagey ${ }^{1}$, Medy \\ Ompi $^{1}$, Khristin I.F. Kondoy ${ }^{2}$
}

1. Program Studi IImu Kelautan, Fakultas Perikanan dan IImu Kelautan, Universitas Sam Ratulangi, Manado

2. Program Studi Manajemen Sumberdaya Perairan, Fakultas Perikanan dan IImu Kelautan, Universitas Sam Ratulangi, Manado

*email : jenitapansing@yahoo.co.id

The brown macroalga Sargassum sp is one of coastal natural resources that have both ecological and economical functions. Information of Sargassum sp in Raja Ampat Archipelago is limited. There are many variations of Sargassum sp morphology, for example, some species have form like thin yarn and have a lot of branches, bubble form, wide leaves form, saw-like leaves form and have wide thallus. The objectives of this study are to identify and describe the morphology of Sargassum sp that found in Raja Ampat Archipelago, West Papua. This study found four Sargassum species, they are $S$. paniculatum, $S$. grevillei, $S$. cristaefolium from Yeftip Yefnawam Island and S. polycystum from Salawati Island.

Keywords : Description, morphology, Sargassum sp., Raja Ampat Archipelago.

Sargassum sp. merupakan salah satu sumberdaya alam pesisir yang memiliki fungsi ekologis dan ekonomis bagi masyarakat pesisir. Di Kepulauan Raja Ampat ini belum banyak alga Sargassum yang di eksplorasi. Alga Sargassum memiliki berbagai macam bentuk morfologi tallus, misalnya ada yang berbentuk seperti benang yang halus, bercabang banyak, berbentuk gelembung, daun yang lebar, bergerigi pada bagian daun dan bertalus lebar.Penelitian ini bertujuan untuk mengetahui jenis dan mendeskripsikan morfologi Sargassum yang ditemukan di Kepulauan Raja Ampat, Papua Barat. Dari hasil penelitian ditemukan ada 4 spesies di Pulau Yeftip Yefnawam (S. paniculatum, S. grevillei, $S$. cristaefolium), dan yang ditemukan di Pulau Salawati (S. polycystum).

Kata Kunci : Deskripsi, Morfologi, Sargassum Sp., Kepulauan Raja Ampat.

\section{PENDAHULUAN}

Kepulauan Raja Ampat yang membentang seluas 4.600.000 ha berada di Pulau Papua dan di sebelah Timur Pulau Halmahera. Diapit oleh Samudera Pasifik di Utara dan Laut Seram disebelah selatan merupakan salah satu kawasan di Indonesia yang memiliki keanekaragaman hayati laut.
Wilayah ini terdapat sekitar 610 pulau dengan pulau besar diantaranya : Pulau Waigeo, Batanta, Salawati dan Misool (Burdam, 2010).

Markoalga merupakan sumber karagenan, agar, dan alginat yaitu Eucheuma, Gracilaria, Gelidium dan Sargassum, selain itu untuk kebutuhan farmasi, kosmetik dan kertas (Gerung, 2006b). 
Weber Van Bosse melaporkan bahwa ada lebih dari 700 spesies makroalga di Indonesia selama ekspedisi Siboga (Weber Van Bosse 1913, 1928).

Beberapa spesies Sargassum yang ditemukan diletak geografis Indonesia yaitu; S. baccularia (Tseng dan Lu Baoren, 1991), S. binderi (Agardh, 1848), S. cinctum (Agradh, 1848), S. polycystum (Agardh, 1824), S. grevillei (Yoshida, 1998b), S. cristaefolium (Calumpong, 1997).

Penelitian ini bertujuan untuk mengetahui jenis dan mendeskripsikan morfologi Sargassum sp. yang berada di Kepulauan Raja Ampat, Papua Barat.

\section{METODE PENELITIAN}

Lokasi penelitian pengambilan sampel alga di Kepulauan Raja Ampat. Penelitian dilakukan selama 3 bulan.

Pengambilan sampel makroalga menggunakan metode survey jelajah di daerah dekat ekosistem mangrove, lamun dan terumbu karang. Sampel Sargassum yang ditemukan ditampung pada plastik sampel kemudian diherbarium selanjutnya diidentifikasi di Lab.Biologi Kelautan, FPIK, UNSRAT.

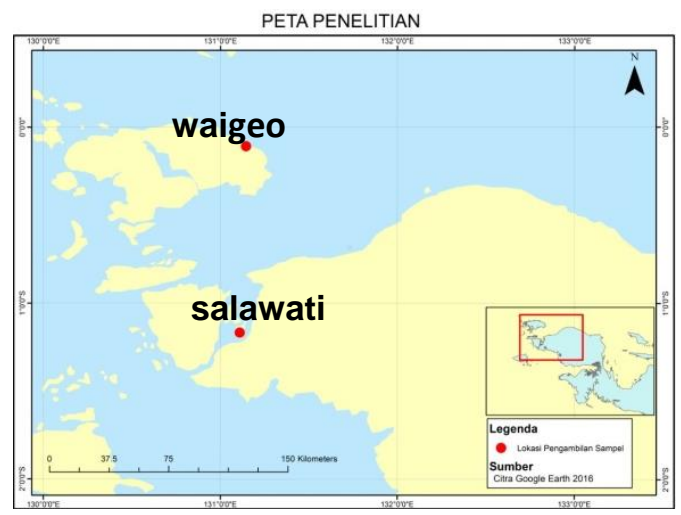

Gambar 1. Peta Lokasi Penelitian

\section{HASIL PENELITIAN}

Di Pulau Wagio (Waigeo Barat Daratan, Pulau Yeftip Yefnawan) yang ditemukan 3 spesies sargassum, sedangkan di pulau Salawati (Pulau Kabra) ditemukan 1 spesies sargassum

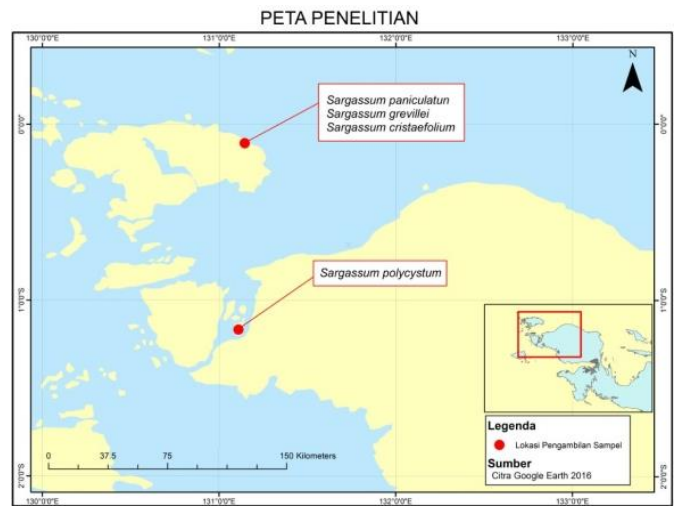

Gambar 2. Lokasi Sargassum sp. yang Ditemukan.

\section{Sargassum paniculatum}

Pada jenis ini memiliki tinggi tallus $30 \mathrm{~cm}$ berwarna coklat, setelah di herbarium yang berubah menjadi coklat tua (Gambar 3).

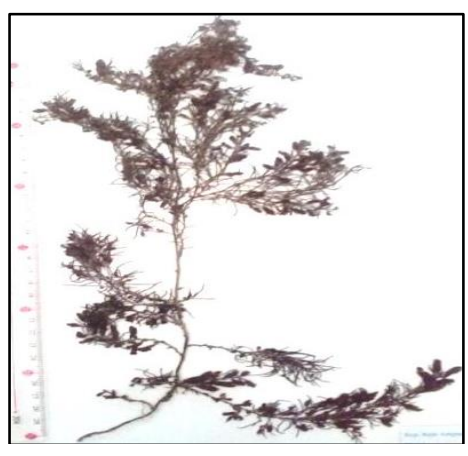

Gambar 3. S.paniculatum 


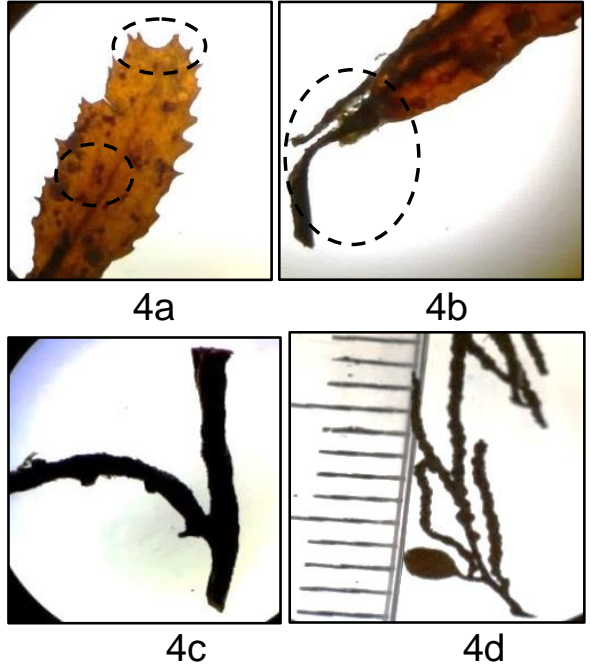

Gambar 4. Foto Morfologi S.paniculatum

Tipe bergerigi agak berjarak terpisah yang ada pada bagian luar ujung daun (Gambar 4), Bagian permukaan daun terdapat banyak bulat seperti gelembung, titik kecil-kecil berwarna hitam (Gambar 4a), Pangkal DaunSedikit meruncing agak kasar pada bagian permukaannya (gambar 4b), Percabangan menyatuh, padat dan banyak (Gambar 4c) dan gelembung atau vesicle (Gambar 4d).

\section{Sargassum grevillei}

Berwarna coklat, memiliki banyak percabang halus, banyak tallus melingkar (Gambar 5).

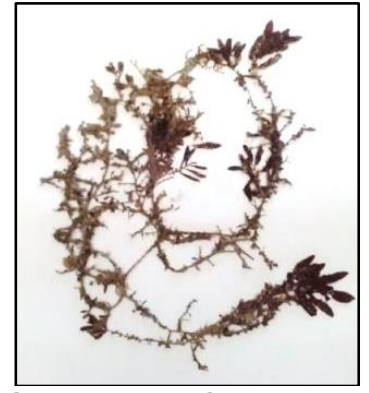

Gambar 5. S. grevillei

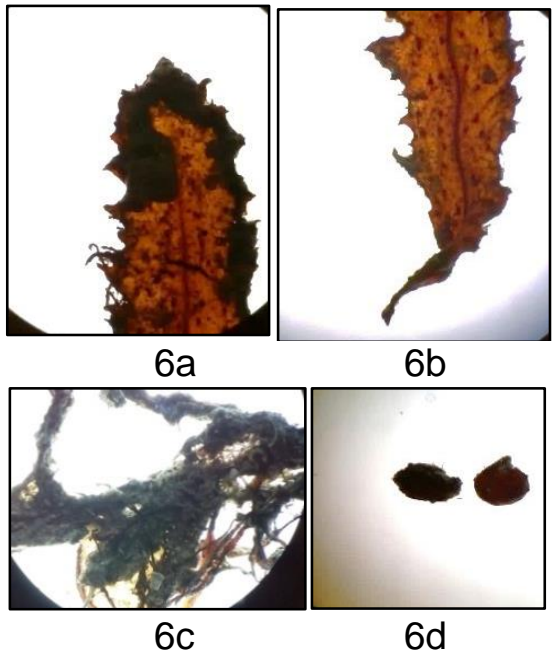

Gambar 6. Foto Morfologi S.grevillei.

Berbentuk meruncing seperti pisau dan bagian samping agak bergerigi (Gambar 6a), Berlengkung agak kecil dan kasar (Gambar 6b), Nampak seperti terlindungi dengan benang yang berwarna putih (Gambar 6c), Bulat seperti gelembung, berwarna coklat, ketika diherbarium akan mengepis (Gambar 6d).

\section{Sargassum polycystum}

Tinggi tallus $24 \mathrm{~cm}$ (Gambar 7) berwarna coklat kemerahan saat kering.

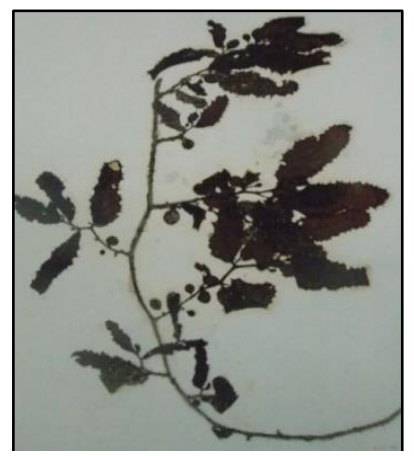

Gambar 7. S. polycystum 

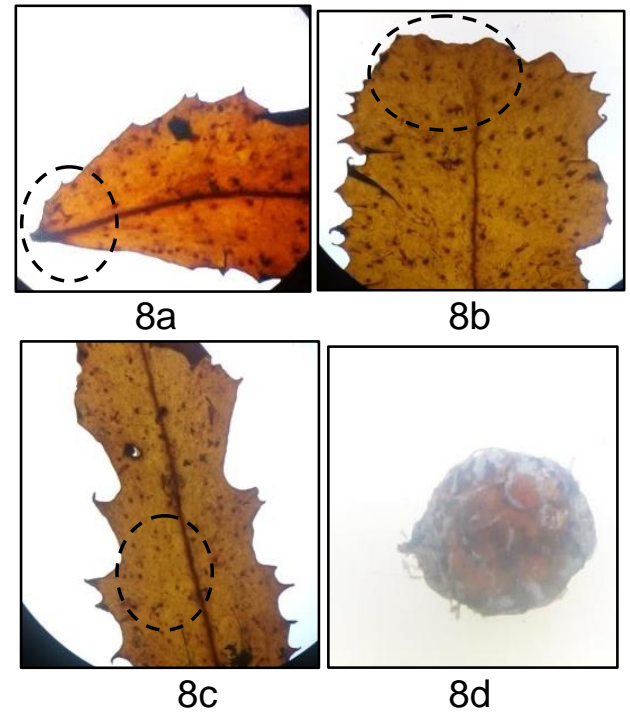

Gambar 8. Foto Morfologi

S. polycystum

Pangkal daun melebar, sedikit meruncing dan terdapat gerigi pada bagian daun (Gambar 8a), Ujung daun bergerigi tapi tidak terlalu dalam, dan agak sedikit mendatar (Gambar 8b), Titik kecil hitam pada daun, agak kasar dan memiliki garis-garis putus (Gambar 8c), gelembung atau vesicle bulat agak besar (tidak mikro) berwarna coklat, setelah diherbarium akan seperti pipih bentuknya (Gambar 8d).

\section{Sargassum cristaefolium}

Tallus saling terikat berwarna agak coklat gelap ketika sudah kering, lebar tallus $7 \mathrm{~cm}$ dan bentuk daun agak seperti gagang bunga runcing rata dan bersusun (Gambar 9).

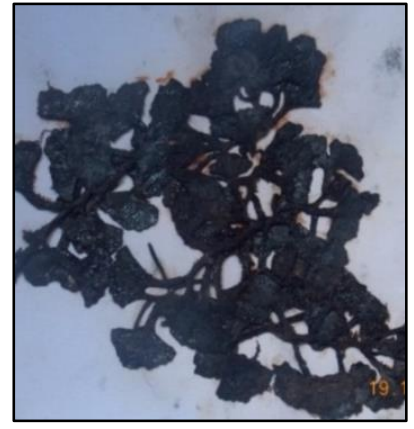

Gambar 9. S.cristaefolium

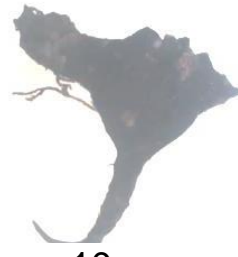

$10 a$

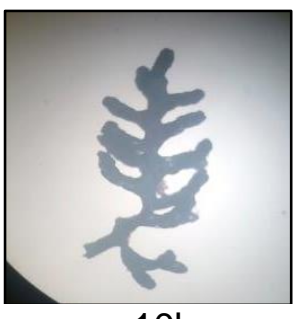

$10 b$

\section{Gambar 10. Foto Morfologi} S. cristaefolium

Tersusun ke atas seperti percabangan halus (Gambar 10a), berwarna coklat tua bentuk daun agak seperti gagang bunga runcing rata dan bersusun (Gambar 10b).

\section{KESIMPULAN}

Dari hasil penelitian ini dapat di simpulkan bahwa : Sargassum yang ditemukan di Kepulauan Raja Ampat tepatnya pada lokasi Pulau Wagio Barat Dan Pulau Salawati yaitu; S. paniculatum, S. grevillei, S. polycystum, S. cristaefolium.

\section{DAFTAR PUSTAKA}

Agardh, C.A. 1824. Sytema Algarum. xxxvii+132pp. Berling, Lund. 
Agardh, J.G. 1848. Species, genera et ordines algarum, Gleerup, Lund. Vol.1. p328.

Burdam V. 2010. Ringkasan Eksekutif Kajian Ekosistem Sumberdaya Alam Hayati Kabupaten Raja Ampat Provinsi Papua Barat.

Calumpong H. P. Dan E. G. Menez. 1997. Field Guide To The Common Manggrove, Seagrass And Algae Of Philipine. Bookmark. Inc.

Gerung, G.S. 2006b. Seaweeds Industry of Indonesia, In Seaweeds Resource of the world 2nd Edition. (eds.Allan T. Chritchley and MasaoOhno), ETI Biolnformatic, Netherland (CD Version).

Tseng, C.K., and Lu Baoren. 1991. Studies on the Malacocarpic Sargassum of china. I. Fruticediferae J.Agardh.

Weber-van Bosse A. 1913. Liste des algues du Siboga I, Myxophyceae,Chlorophycea, Phaeophyceae,Siboga Expditie 59a: 1-186.

Weber-van Bosse A. 1928. Liste des algues du Siboga IV, Rhodophyceae, troisieme partie, Gigartinales et Rhodymeniales. SibogaExpeditie Monograph LIX d.: 393-533.

Yoshida, T. 1998b. Section 1. Western Pacific Asiatic species sargassum subgenus sargassum: with keys to the species. Introduction. In abbott, I. A., ed. Taxonomy of economic seaweeds: with reference to some Pacific and Caribbean species, Vol.2. California Sea Grant College Program, University of California, La Jolla, Calif., pp. 1-3. 